\title{
Distribution of $\beta$-Lactamases A and B in some Groups of Yersinia enterocolitica and their Role in Resistance
}

\author{
By G. COR NELIS \\ Laboratoire de Microbiologie, Université de Louvain, B I200 Brussels, Belgium
}

(Received I2 June 1975; revised I7 July 1975)

\begin{abstract}
SUMMARY
Yersinia enterocolitica w222 (serological group 3) synthesized two different intracellular $\beta$-lactamases, called A and B. Enzyme B was more sensitive than A to inhibition by cloxacillin. The minimum inhibitory concentrations of various $\beta$-lactam antibiotics for strains of $Y$. enterocolitica of groups 3 and 9 and the effect of cloxacillin on these concentrations suggested differential roles for $\beta$-lactamases of types A and B in penicillin and cephalosporin resistance. Type B enzymes protected $Y$. enterocolitica against cephalothin and cephalosporin $\mathrm{C}$, whereas type A enzymes protected very efficiently against carbenicillin. Protection against other $\beta$-lactam antibiotics was exerted by both enzymes. However, while both enzymes readily hydrolysed cephaloridine and showed no crypticity with this substrate, they only conferred a very weak protection against it. This may be because cephaloridine reached its target quickly, before it was degraded. The resistance of strains of $Y$. enterocolitica from groups I, 2 and I 6 was also explicable in terms of a two-enzyme system, whereas strains belonging to group $5 \mathrm{~b}$ produced only a type B lactamase and were sensitive to carbenicillin.
\end{abstract}

\section{INTRODUCTION}

Antibiotics of the $\beta$-lactam group are relatively ineffective against Yersinia enterocolitica (Nilhen, 1967, 1969; Wauters, 1970; Zen-Yoji \& Maruyama, 1972) and strains of this species are $\beta$-lactamase producers (Cornelis, Wauters \& Vanderhaeghe, I973; Mishankin, Ryzhko \& Grigorian, 1973). While all the different serological groups (Winblad, 1967, I968; Wauters, Le Minor \& Chalon, 197I; Wauters et al. 1972) of Y. enterocolitica are $\beta$-lactamase producers, they differ from one another in the pattern of their sensitivities to $\beta$-lactam antibiotics (Cornelis et al. 1973).

An attempt to purify the $\beta$-lactamase from strain W222 (chosen at random among group 3 strains) revealed that this strain produced two different $\beta$-lactamases which have been called $A$ and B. Three other strains from group 3 and two strains from group 9 also had two lactamases. In contrast, strain $\mathrm{H66}$, an unusual carbenicillin-sensitive strain, synthesized only one lactamase which was very similar to B (Cornelis \& Abraham, 1975). Among the characteristics which distinguished $\beta$-lactamases $\mathrm{A}$ and $\mathrm{B}$ were their sensitivity to inhibitors: A was more sensitive to thiol reagents, and B to inhibition by cloxacillin (Cornelis \& Abraham, 1975).

My aim was to assess the respective roles of these two $\beta$-lactamases in the resistance of $Y$. enterocolitica to $\beta$-lactam antibiotics. Three methods were used. One involved the determination of the minimum inhibitory concentration (m.i.c.) of each of a number of $\beta$-lactam antibiotics for strains from different groups, including strain $\mathrm{H} 66$ and a mutant specifically impaired in ability to produce one of the two lactamases. A second involved a 
study of the selective effect of cloxacillin and other B-enzyme inhibitors on the pattern of m.i.c. values. The third method determined the response to different $\beta$-lactam antibiotics of crude extracts of strains from the different groups, to correlate the enzymic properties of these extracts with the m.i.c. data. The present work deals with the serological groups 3,9 and $5 \mathrm{~b}$, mainly encountered in man, and $\mathrm{I}, 2$ and $\mathrm{I} 6$ usually encountered in animals (Nilhen, 1969; Wauters, 1970; Zen-Yoji et al. 1973; Aldova \& Lim, 1974). Groups 9 and 5b show the same biochemical behaviour and are therefore classified in the same biotype; the remaining groups belong to different biotypes (Wauters, I970).

\section{METHODS}

Strains. The strains studied were the same as those used by Cornelis et al. (1973) except that V.2.73, an R factor-carrying strain, was omitted and sixteen strains of serotype $5 \mathrm{~b}$ were added. The latter strains were also members of Professor G. Wauters' (Louvain) collection. They include the two sole indole $(-) 5$ b strains of this collection (Ye850 isolated by Weaver, and TIIo isolated by Toma).

Minimum inhibitory concentrations. These values were determined by the agar dilution method (Ericsson \& Sherris, 197I) using a multipoint inoculator (Denley, Bolney, Sussex). At each step in a series of dilutions, the concentration of antibiotic was increased by a factor of two. The medium was Mueller-Hinton agar (Difco) supplemented with $5 \%(\mathrm{v} / \mathrm{v})$ defibrinated horse blood. The plates were incubated for $24 \mathrm{~h}$ at $29^{\circ} \mathrm{C}$.

Isolation of a carbenicillin-sensitive mutant. A broth culture $(5 \mathrm{ml})$ of strain $\mathrm{w} 238$ in the exponential phase of growth was centrifuged and the pellet resuspended in $5 \mathrm{ml}$ of $0.066 \mathrm{M-}$ phosphate buffer pH 6.0 containing the mutagen $N$-methyl- $N^{\prime}$-nitro- $N$-nitrosoguanidine (NTG; $30 \mu \mathrm{g} / \mathrm{ml}$; Fluka A.G., Buchs, Switzerland). This suspension was incubated for I5 min at $37{ }^{\circ} \mathrm{C}$, then centrifuged and washed twice in $5 \mathrm{ml}$ buffer; $0.1 \mathrm{ml}$ of the washed bacterial suspension was transferred to $5 \mathrm{ml}$ broth and incubated overnight. The mutagenized culture was then diluted and plated on tryptic soy agar (TSA; Difco). Plates bearing separated colonies were replicated on TSA containing carbenicillin $(100 \mu \mathrm{g} / \mathrm{ml})$ or cephalosporin C $(200 \mu \mathrm{g} / \mathrm{ml})$. Of 1600 colonies replicated, ten did not grow, or grew poorly, on carbenicillin. Of these, only one (W2380I) was a carbenicillin-sensitive mutant.

Detection of synergy by a diffusion method. The bacteria were inoculated on TSA or Mueller-Hinton agar in order to yield a dense but not completely confluent growth. Samples $(50 \mu \mathrm{l})$ of the antibiotic solutions to be tested were placed in $7 \mathrm{~mm}$ diameter holes punched in the agar at a distance of $17 \mathrm{~mm}$ (centre to centre) from each other. The concentrations were 2 and $4 \mathrm{mg} / \mathrm{ml}$ with cephalosporin C, $0.25,0.5$ and I.0 mg/ml with cephalothin, and 0.062 and $0.125 \mathrm{mg} / \mathrm{ml}$ with cephaloridine. The methicillin concentrations were $\mathrm{I} \cdot 0$ and $2.0 \mathrm{mg} / \mathrm{ml}$ for strain $\mathrm{W} 222$ and 0.25 and $0.5 \mathrm{mg} / \mathrm{ml}$ for strain $\mathrm{H} 66$. The carbenicillin concentrations were $0.5, \mathrm{I} \cdot 0$ and $2.0 \mathrm{mg} / \mathrm{ml}$.

Growth. The cultures were grown as previously described (Cornelis \& Abraham, I975), except that normal $500 \mathrm{ml}$ conical flasks shaken at $250 \mathrm{rev} / \mathrm{min}$ were used and the temperature was 29 instead of $27^{\circ} \mathrm{C}$. Growth was followed with a Klett-Summerson colorimeter (New York, U.S.A.) using filter W66. I attempted to induce the formation of a $\beta$-lactamase by adding 6-aminopenicillanic acid after $4 \mathrm{~h}$ growth. The bacteria were harvested after $7 \mathrm{~h}$ growth.

Preparation of crude extracts. This was done as described by Cornelis \& Abraham (1975), except that the thawed bacteria were mixed with water instead of phosphate buffer. The ultrasonic disintegrator was a Branson (Danbury, Connecticut, U.S.A.) sonifier (80 W, 
$20 \mathrm{kHz}$ ) equipped with a microtip. The time of centrifugation (100000 $\mathrm{g}$ ) was decreased to I $\mathrm{h}$. Crude extracts to be kept for some days were immediately dialysed against phosphate buffer $(0.025 \mathrm{M}, \mathrm{pH} 7 \cdot 3)$.

Starch gel electrophoresis was performed according to Smithies (1955). The gels were made up of $15 \mathrm{~g}$ hydrolysed starch (Connaught, Toronto, Canada) in $100 \mathrm{ml}$ of $0.03 \mathrm{M}$-borate buffer, $\mathrm{pH} 7.5$ or 8.0 . The electrolyte ( $400 \mathrm{ml}$ in each compartment) was the same buffer at $0.3 \mathrm{M}$. Samples $(5 \mu \mathrm{l})$ were absorbed on small strips $(10 \times \mathrm{I} \mathrm{mm}$ ) of Whatman No. 3 paper. Runs were made for $2.5 \mathrm{~h}$ under constant voltage $(300 \mathrm{~V})$ in a Shandon U77 apparatus. The enzymes were revealed by the method of Jack \& Richmond (1970): the gels were sprayed with a solution containing benzylpenicillin (Io mg/ml), $0.016 \mathrm{M}-\mathrm{I}_{2}, 0 . \mathrm{I} 2 \mathrm{M}-\mathrm{KI}$ and $0.066 \mathrm{M}$ phosphate buffer, $\mathrm{pH} 6.5$. This coloured the gels blue and after a few minutes incubation at $37^{\circ} \mathrm{C}, \beta$-lactamases appeared as colourless zones. Samples of enzymes A and B from w222 (group 3) were used as references (Cornelis \& Abraham, 1975). A crude extract of Y.pseudotuberculosis 360 was used as a negative control of the lactamase staining. Enzyme A remained at the origin, rather on the cathodic side of the strip, while enzyme B moved towards the anode.

Assay of $\beta$-lactamases. $\beta$-Lactamase activity is expressed as $\mu \mathrm{mol}$ substrate hydrolysed $/ \mathrm{min} /$ $\mathrm{ml}$ enzyme solution, at $30^{\circ} \mathrm{C}$ and $\mathrm{pH} 6.5$. The rate of hydrolysis was determined by the alkalimetric method as previously described (Cornelis \& Abraham, 1975). The apparatus (Radiometer, Copenhagen, Denmark) comprised a pH meter 6I, a TT 60 titrator, an ABU I2 autoburette and a Rec 6r servograph. The alkali was $50 \mathrm{~mm}-\mathrm{NaOH}$ instead of $40 \mathrm{mM}-\mathrm{NaOH}$.

Small-scale preparation of enzyme B from strain $\mathrm{w} 238$. After $48 \mathrm{~h}$ dialysis, $0.5 \mathrm{ml}$ crude extract from strain $\mathrm{W} 238$ was applied to a small column $(\mathrm{I} 7.5 \times 0.5 \mathrm{~cm})$ containing $3 \mathrm{ml}$ Sephadex CM-50 (Pharmacia) equilibrated with 0.025 M-phosphate buffer pH 7.3. Enzyme B passes straight through the column while enzyme A is retained (Cornelis \& Abraham, 1975). The first active fraction was recovered and checked by starch gel electrophoresis for lack of enzyme A.

Substrates and inhibitors. Benzylpenicillin was from Ludeco, Brussels, Belgium; cephalosporin C and cephaloridine were from Glaxo Research Ltd, Greenford, Middlesex; cephalothin, cephalexin and cefamandole were from Eli Lilly \& Co., Indianapolis, U.S.A.; 6-aminopenicillanic acid (6APA), cloxacillin, methicillin, carbenicillin and ampicillin were from Beecham Research Laboratories, Brockham Park, Surrey; oxacillin was from Bristol Benelux, Brussels, Belgium; cefoxitin was from Merck Sharp and Dohme, Rahway, New Jersey, U.S.A.

\section{RESULTS}

\section{Minimum inhibitory concentrations}

The m.i.c. values of some penicillins and cephalosporins were determined for all the strains mentioned in Methods. As observed before (Cornelis et al. 1973), the m.i.c. values were generally very similar for strains within each serological group. Table I gives only the most frequently observed value, with each antibiotic, for strains of each group. The individual and experimental variations were normally one dilution and very exceptionally two dilutions (i.e. a factor of two or four between the m.i.c. values). However, within group 2, the individual variation in the m.i.c. for cephalosporin $\mathrm{C}$ was unusually high and the values for the two extreme strains are given in Table I. The m.i.c. values for Y.pseudotuberculosis, which does not produce a detectable $\beta$-lactamase (Cornelis et al. I973; Mishankin et al. 1973), have been determined for comparison. As Cornelis et al. (1973) noted, group 5b 


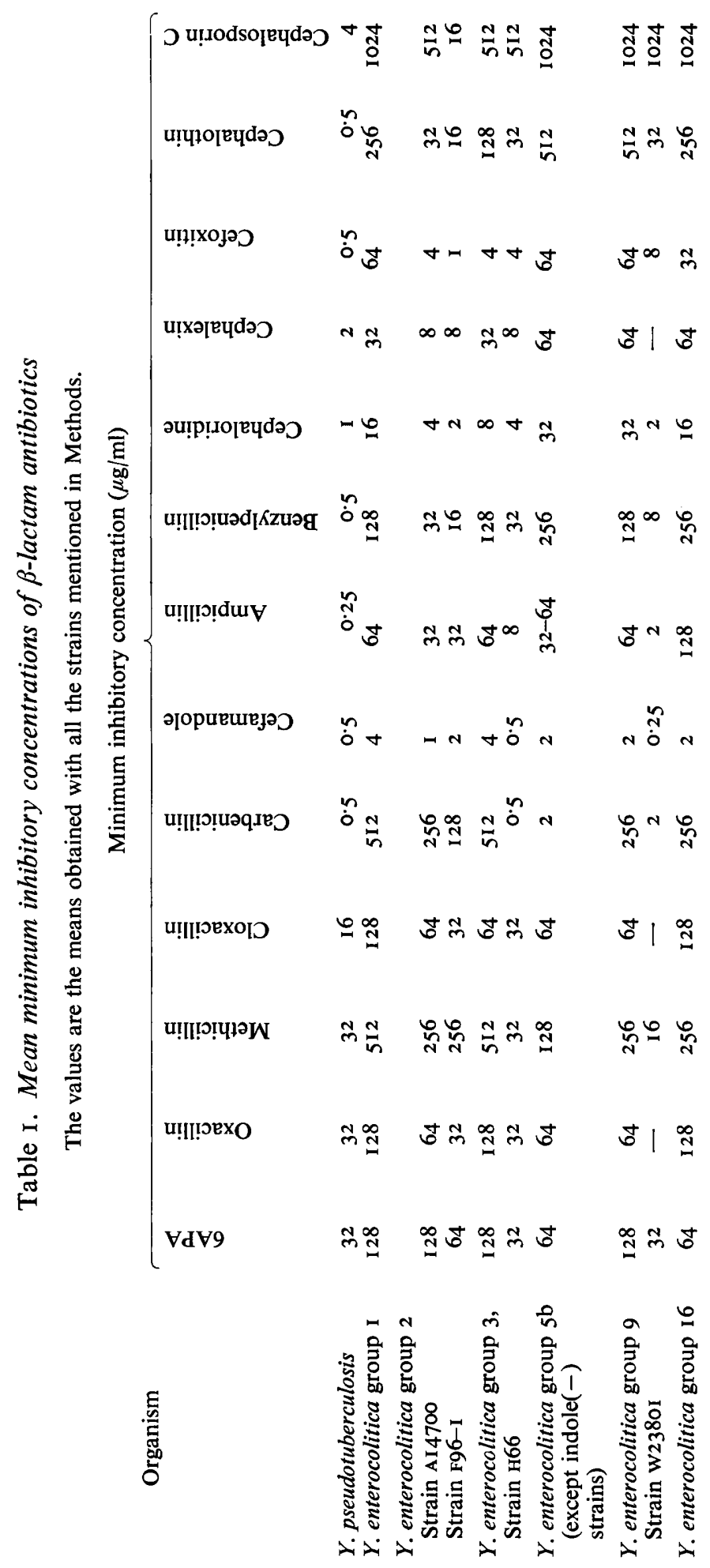




\section{Table 2. Inhibition of $Y$. enterocolitica $\beta$-lactamases by poorly hydrolysed $\beta$-lactam antibiotics}

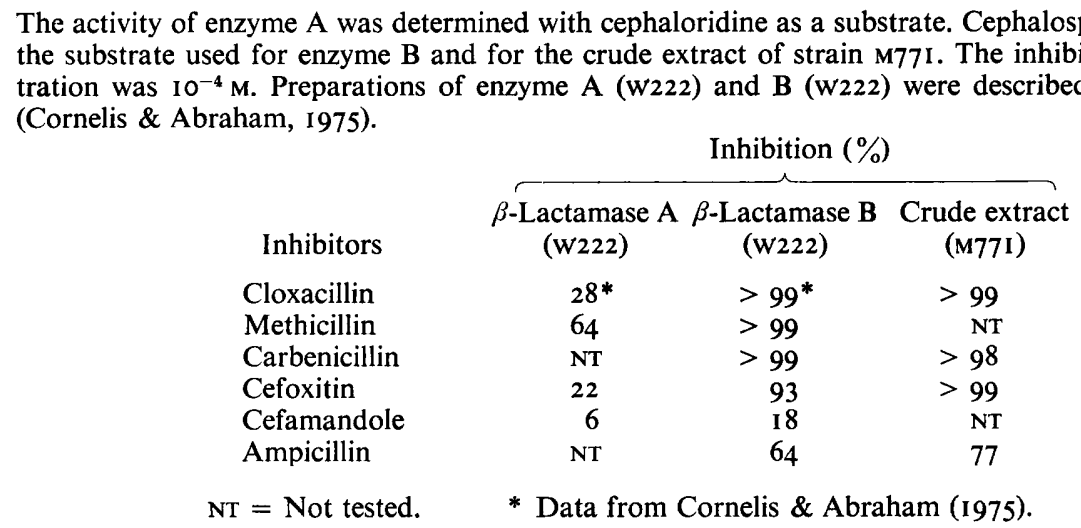

contrasts strikingly with the other groups in the m.i.c. values for carbenicillin. The indole $(-)$ strains, however, appear as resistant to carbenicillin as strains belonging to other groups. Group 3 strains are highly resistant to carbenicillin and cephalosporin C, except strain $H 66$ which is highly resistant to cephalosporin $C$ but sensitive to carbenicillin. The strains from group 9 are also very resistant to carbenicillin and cephalosporin C. Strain w2380r, a carbenicillin-sensitive mutant from strain W238, remained highly resistant to cephalosporin $\mathrm{C}$ and moderately resistant to cephalothin.

\section{$\beta$-Lactamase inhibition in vitro by $\beta$-lactam antibiotics}

Cloxacillin $\left(\mathrm{IO}^{-4} \mathrm{M}\right)$ completely inhibits the activity of enzyme B but only partially that of enzyme A (Cornelis \& Abraham, 1975). Other $\beta$-lactam antibiotics which are poorly hydrolysed are also inhibitors of enzyme B (Table 2), among them carbenicillin, cefoxitin (a 7-methoxycephalosporin) and ampicillin. On the other hand, ampicillin and carbenicillin are substrates from enzyme A (Cornelis \& Abraham, 1975), while cefoxitin, which is not hydrolysed by $\mathrm{A}$, is only a poor inhibitor of this enzyme.

\section{Synergy with different $\beta$-lactam antibiotics}

Since enzyme $\mathrm{B}$ can be inhibited in vitro by certain $\beta$-lactam antibiotics which act as substrate analogues, synergy between these inhibitors and different $\beta$-lactam antibiotics seemed possible, as with some other $\beta$-lactamase-producing Gram-negative bacteria (Hamilton-Miller, Smith \& Knox, 1964; Sabath \& Abraham, 1964; Sutherland \& Batchelor, 1964; Hamilton-Miller, 197I). Using a diffusion method, synergism was clear between methicillin and cephalosporin C, or cephalothin, with strains w222 and H66. Synergism was also evident from the considerable falls ( 3 to 5 dilutions) in the m.i.c. values for cephalosporin $\mathrm{C}$ against strains of all the groups when cloxacillin ( 10 or $20 \mu \mathrm{g} / \mathrm{ml}$ ) was present. Since enzyme B is more sensitive than enzyme A to inhibition by cloxacillin, the degree of synergy between cloxacillin and various penicillins and cephalosporins was used to assess the respective roles of these two enzymes in resistance. For each determination of m.i.c. values, the strains were inoculated in parallel on solid medium with and without cloxacillin $\left(20 \mu \mathrm{g} / \mathrm{ml}, 4 \times 10^{-5} \mathrm{M}\right)$. There was again a great uniformity within the groups and the results have been condensed (Table 3). The number of dilutions are recorded between the m.i.c. 


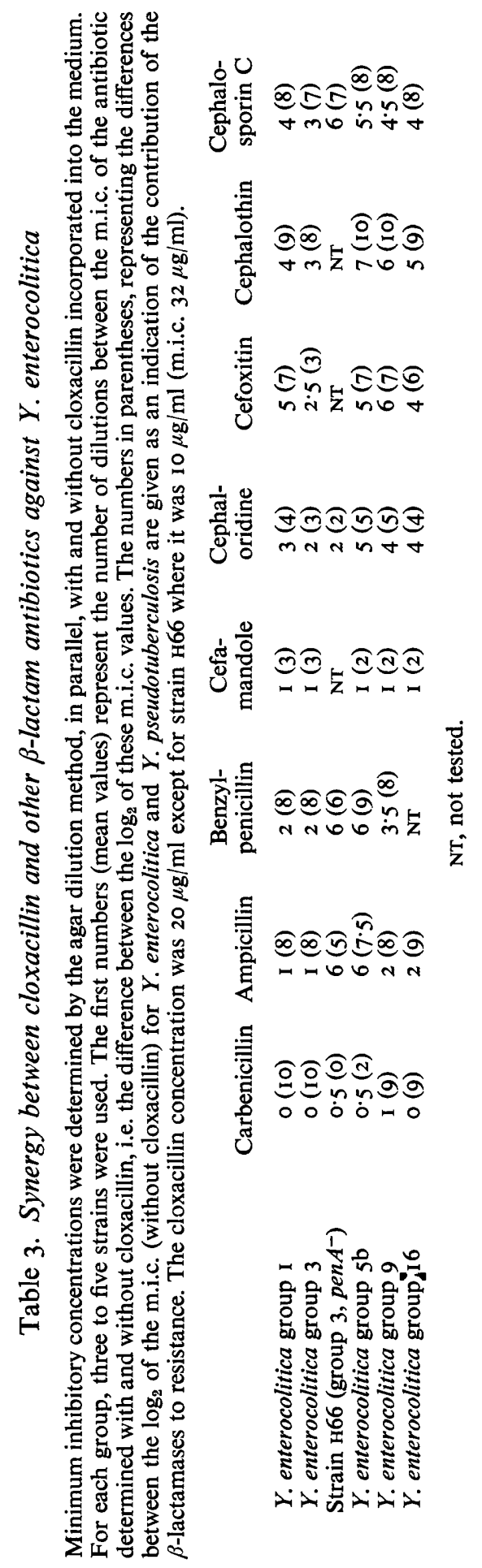


Table 4. Synergy between carbenicillin and other $\beta$-lactam antibiotics for Y. enterocolitica

Minimum inhibitory concentrations were determined by the agar dilution method, in the absence of carbenicillin and in its presence at various concentrations (20 to $100 \mu \mathrm{g} / \mathrm{ml})$.

\begin{tabular}{|c|c|c|c|c|c|c|c|c|c|c|c|c|}
\hline \multirow{3}{*}{$\begin{array}{l}\text { Carbenicillin } \\
\text { concn }(\mu \mathrm{g} / \mathrm{ml})\end{array}$} & \multicolumn{11}{|c|}{ Minimum inhibitory concentration $(\mu \mathrm{g} / \mathrm{ml})$} & \\
\hline & & \multicolumn{3}{|c|}{ Ampicillin } & \multicolumn{4}{|c|}{ Cephalosporin $\mathrm{C}$} & \multicolumn{4}{|c|}{ Cephalothin } \\
\hline & 0 & 20 & 50 & 100 & 0 & 20 & 50 & 100 & 0 & 20 & 50 & 100 \\
\hline Group I (yer 28) & 64 & 32 & I 6 & 8 & 2048 & 256 & 32 & 4 & 256 & 32 & 8 & 8 \\
\hline Group 2 (AI4700) & 32 & 16 & 16 & 16 & 512 & I 28 & 64 & 32 & 32 & 16 & 8 & 8 \\
\hline $\begin{array}{l}\text { Group } 3 \text { (w223, } \\
\text { w224, w237, w239) }\end{array}$ & 64 & 32 & 32 & 32 & 512 & $64-128$ & 64 & $32-64$ & 128 & 32 & I6 & 16 \\
\hline $\begin{array}{l}\text { Group } 9 \text { (W228, } \\
\text { W244, W410) }\end{array}$ & 64 & 32 & $16-32$ & I6 & 1024 & 512 & 256 & I 28 & $5 \mathrm{I} 2$ & 32 & I 6 & I6-8 \\
\hline Group I 6 (AZI 523) & I 28 & I 6 & 8 & 4 & 1024 & 512 & 128 & 32 & 256 & 16 & 8 & 4 \\
\hline
\end{tabular}

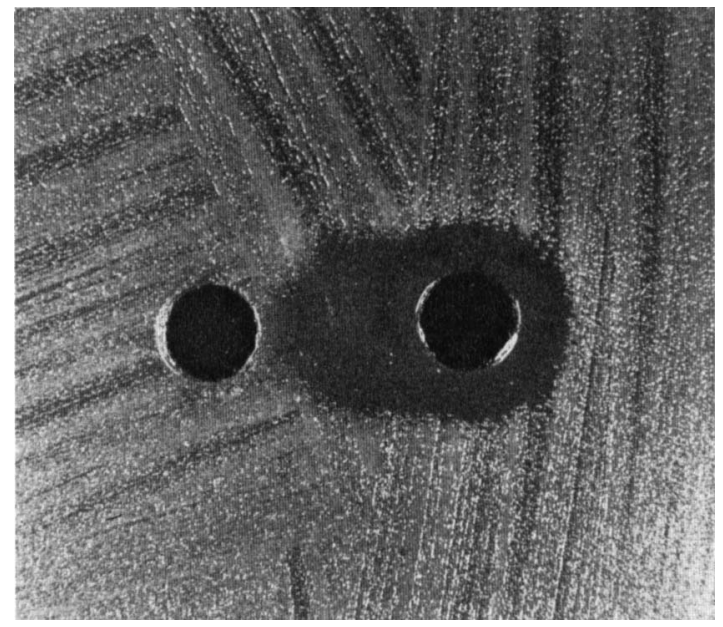

Fig. I. Synergy between carbenicillin and cephalosporin $\mathrm{C}$. The plate was seeded with $Y$. enterocolitica strain W239 (group 3). Left: carbenicillin ( $\mathrm{I} \mathrm{mg} / \mathrm{ml}$ ); right: cephalosporin $\mathrm{C}$ (4 mg/ml). Each hole received $50 \mu \mathrm{l}$ antibiotic solution.

values with and without cloxacillin, i.e. the differences between the $\log _{2}$ of the two values. Cloxacillin at $10 \mu \mathrm{g} / \mathrm{ml}$ gave results which were either identical or one unit lower.

For the groups I, 3, 9 and I6, the effect of cloxacillin was far from uniform, even when only the antibiotics with very high m.i.c. values are compared. Synergy was very marked with cephalosporin $\mathrm{C}$ and cephalothin while it was not, or nearly not, observable with carbenicillin. Moreover, synergy was generally greater in group 9 than in group 3 . By contrast, this differential synergy between cloxacillin and other $\beta$-lactam antibiotics was not observed for strain $\mathrm{H} 66$ and those of group $5 \mathrm{~b}$, if the results with carbenicillin (to which these strains are already fully sensitive in the absence of inhibitor) are neglected.

Since carbenicillin is a substrate for enzyme A but an inhibitor for enzyme B, synergy was looked for between carbenicillin (at 20,50 and $100 \mu \mathrm{g} / \mathrm{ml}$ ) and other $\beta$-lactam antibiotics, with the $Y$. enterocolitica groups highly resistant to carbenicillin. Synergy was found between 


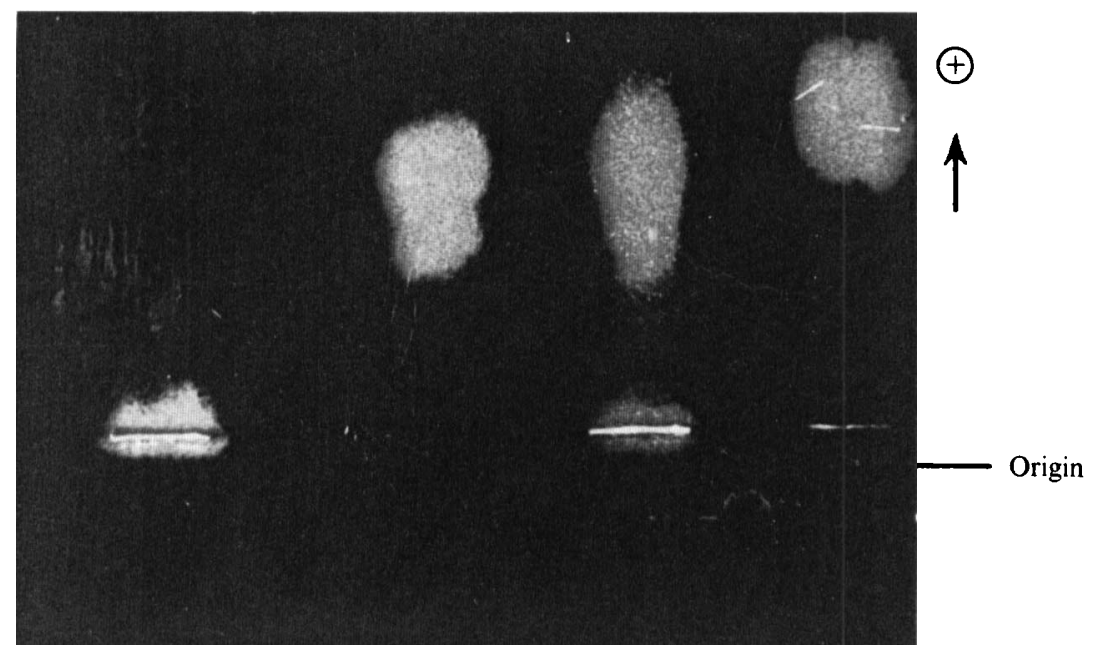

I

II

III

IV

Fig. 2. Starch gel electrophoresis at pH 7.5 of enzymes A (I) and B (IV) from strain w222 (group 3) and crude extracts from strains M77I (group 5b, II) and W238 (group 9, III). The $\beta$-lactamases were stained with benzylpenicillin and iodine.

carbenicillin and the three other $\beta$-lactam antibiotics tested (Table 4). As when cloxacillin wasinhibitor, the effect was greater for cephalothin and cephalosporin $\mathrm{C}$ than for ampicillin. For group $5 \mathrm{~b}$, carbenicillin was used at a concentration of $0.5 \mu \mathrm{g} / \mathrm{ml}(\mathrm{m}$.i.c. $2 \mu \mathrm{g} / \mathrm{ml}$ ), but no synergistic effect could be detected at this concentration $\left(\simeq 10^{-6} \mathrm{M}\right)$. Synergy between carbenicillin and cephalothin, or cephalosporin $\mathrm{C}$, was also revealed by the diffusion technique with the group 3 strain w239 (Fig. I). With those groups for which the m.i.c. of cefoxitin alone was $64 \mu \mathrm{g} / \mathrm{ml}$, m.i.c. values were determined for cephalosporin $\mathrm{C}$ and cefoxitin $(20 \mu \mathrm{g} / \mathrm{ml})$ together. In contrast to the result with cloxacillin and cephalosporin $\mathrm{C}$, only a slight synergy (I dilution) could be observed.

\section{$\beta$-Lactamase $A$ and $B$ content of crude extracts}

In general, starch gel electrophoresis of crude extracts of strains F96-I, AI4700 and W238 (groups 2 and 9) indicated that both enzymes A and B were present. Strain M77I (group 5b), on the other hand, exhibited only one spot which corresponded to B (Fig. 2). The B-like spot of strain w2380I corresponded with that of w238, but the A-like spot was weak compared with that of W238. The $\beta$-lactamase in the crude extract from strain yeIIo (group I) appeared to separate into two spots, but these were closer together than those of A and B: the enzyme with the greater mobility, which seemed to be present in the greater amount, migrated less far than $B$, while the other migrated slightly towards the anode. Strain AZr 523 (group I6) gave only a diffuse band of low mobility, with a slight constriction in the middle.

\section{Comparison of the characteristics of the enzyme from strains W222, W238 and M771}

A preparation of the B-like enzyme from strain w238 was obtained by small-scale chromatography on Sephadex CM-50. The substrate profile of this preparation was compared with the profile of B (W222) and the crude extracts from w238 and M77I (Table 5). This revealed that B (W222), B (W238) and M77I have similar profiles, but that B (W238) 
Table 5. Substrate profiles

The rates of hydrolysis were determined with a pH stat, at $30^{\circ} \mathrm{C}$ and $\mathrm{pH} 6.5$, with substrate concentration of $2 \mathrm{mg} / \mathrm{ml}$. The rates are relative to an arbitrary value of 100 for benzylpenicillin. The numbers in parentheses identify the strains from which the $\beta$-lactamase was extracted.

\begin{tabular}{|c|c|c|c|c|c|}
\hline \multirow[b]{2}{*}{ Substrate } & \multicolumn{5}{|c|}{ Rates of hydrolysis (relative) by } \\
\hline & $\begin{array}{c}\text { Enzyme A } \\
(\mathrm{w} 222)^{*}\end{array}$ & $\begin{array}{c}\text { Enzyme B } \\
(\mathrm{w} 222)^{*}\end{array}$ & $\begin{array}{c}\text { Enzyme B } \\
(\mathrm{w} 238) \dagger\end{array}$ & $\begin{array}{l}\text { Crude extract } \\
\text { (strain M77I, } \\
\text { group 5b) }\end{array}$ & $\begin{array}{l}\text { Crude extract } \\
\text { (strain w238, } \\
\text { group 9) }\end{array}$ \\
\hline Cephalosporin $\mathrm{C}$ & 35 & 605 & 450 & 324 & IOI \\
\hline Cephaloridine & 300 & 277 & $22 I$ & 190 & 214 \\
\hline Cephalothin & I34 & 214 & NT & 86 & NT \\
\hline Benzylpenicillin & 100 & I0O & 100 & 100 & 100 \\
\hline Ampicillin & 77 & $<\mathrm{I}$ & NT & $\leqslant 2$ & NT \\
\hline Carbenicillin & 25 & $<\mathrm{I}$ & NT & $<\mathrm{I}$ & NT \\
\hline
\end{tabular}

Table 6. Specific enzyme activities and inducibility

For most strains, three inducer concentrations were used $(500 \mu \mathrm{g} / \mathrm{ml}, 200$ or $250 \mu \mathrm{g} / \mathrm{ml}$, and 750 or $1000 \mu \mathrm{g} / \mathrm{ml}$ ). For strains $\mathrm{H} 66$ and $\mathrm{W} 238 \mathrm{OI}$, the range of inducer concentration was lower ( $100 \mu \mathrm{g} / \mathrm{ml}, 200$ or $250 \mu \mathrm{g} / \mathrm{ml}$, and $500 \mu \mathrm{g} / \mathrm{ml}$ ).

\begin{tabular}{|c|c|c|c|}
\hline \multirow[b]{3}{*}{ Strain } & \multicolumn{3}{|c|}{$\begin{array}{l}\mathrm{IO}^{2} \times \text { enzyme activity (enzyme units } / \mathrm{mg} \text { dry } \mathrm{w} \\
\text { organisms) against: }\end{array}$} \\
\hline & \multirow[b]{2}{*}{$\begin{array}{c}\text { Cephaloridine. } \\
\text { Non-induced }\end{array}$} & \multicolumn{2}{|c|}{ Cephalosporin $\mathrm{C}$} \\
\hline & & Non-induced & Induced \\
\hline YeI IO (group I) & $10 \cdot 0$ & $5 \cdot 0$ & $7 \cdot 8$ \\
\hline Al4700 (group 2) & $9 \cdot 3$ & $2 \cdot I$ & $2 \cdot 2$ \\
\hline F96·I (group 2) & $7 \cdot 7$ & $1 \cdot 2$ & $I \cdot O$ \\
\hline w222 (group 3) & $14 \cdot 1$ & $4 \cdot 3$ & $7 \cdot 3$ \\
\hline w239 (group 3) & $13 \cdot 2$ & $3 \cdot 2$ & $4 \cdot 3$ \\
\hline H66 (group 3) & - & 0.6 & $7 \cdot 0$ \\
\hline M77I (group 5b) & $5 \cdot 3$ & $9 \cdot 0$ & 10.5 \\
\hline w238 (group 9) & I I 8 & $6 \cdot 2$ & $10 \cdot 8$ \\
\hline W2380I (group 9) & $5 \cdot 9$ & $6 \cdot 4$ & $7 \cdot 3$ \\
\hline AZI 523 (group I6) & $4 \cdot 8$ & $2 \cdot 2$ & 2.6 \\
\hline
\end{tabular}

-, Not tested in this experiment because this strain possesses only the inducible enzyme $\mathbf{B}$.

and M77I are relatively more active against benzylpenicillin. The $\beta$-lactamase activity of M77I crude extract was strongly inhibited by cloxacillin, carbenicillin and cefoxitin $\left(\mathrm{IO}^{-4} \mathrm{M}\right)$ and also partially inhibited by $\mathrm{IO}^{-4} \mathrm{M}$-ampicillin (Table 2 ).

\section{Specific activity and inducibility of $\beta$-lactamases of crude extracts}

Since it may be assumed that the activity in vitro against cephaloridine is mainly due to enzyme $A$, while that against cephalosporin $C$ is mainly due to $B$ (see substrate profiles), the specific activities of the crude extracts from the different strains were determined with these two substrates. However, an earlier study of strains W222 and H66 (Cornelis \& Abraham, 1975) had revealed that enzyme B was inducible. Consequently, a study was made of the ability of 6APA to act as an inducer with all the strains. The activity of strain 
H66 against cephalosporin C was increased about ten times by addition of 6APA $(200 \mu \mathrm{g} / \mathrm{ml})$ (Table 6). For the strains W238 (group 9), w222 (group 3) and yeI Io (group I), only a slight increase in activity was observed with 6APA at 500 or $750 \mu \mathrm{g} / \mathrm{ml}$ (induction ratio $\mathrm{x} \cdot 6$ or $\mathrm{r} \cdot 7$ ) while there was no effect, or nearly none, with the other strains.

\section{Crypticity}

To examine the accessibility barrier in $Y$. enterocolitica towards some $\beta$-lactam antibiotics, the $\beta$-lactamase activity of intact bacteria from strain w239 (group 3) was compared with that of sonically disrupted bacteria, with these antibiotics as substrates. These two values were identical when cephaloridine was substrate. The activity of disrupted bacteria was 3 times higher with cephalosporin $C$, four times with cephalothin, seven times with cefamandole and 7.5 times with benzylpenicillin. With carbenicillin, the ratio was higher than 50.

\section{DISCUSSION}

Role of $\beta$-lactamases $A$ and $B$ in the resistance of $Y$. enterocolitica 3 and 9. The m.i.c. patterns of the strains of $Y$. pseudotuberculosis and the strains of $Y$. enterocolitica, including H66, suggest that resistance to carbenicillin is correlated with the presence of $\beta$-lactamase type $\mathrm{A}$. On the other hand, resistance to cephalosporin $\mathrm{C}$ seems to be mainly associated with the presence of enzyme B. The m.i.c. pattern of the mutant w2380 I (group 9) leads to the same conclusion. The crude extract of this mutant is specifically impaired in its ability to hydrolyse cephaloridine, in agreement with the diminution of the electrophoretic spot corresponding to type A enzyme.

The idea that resistance to cephalosporin $\mathrm{C}$ is mainly due to enzyme $\mathrm{B}$, while the resistance to carbenicillin is mainly due to enzyme $A$, is also consistent with the results of the experiments on synergism. The $B$ inhibitor (cloxacillin) is synergistic with cephalosporin $C$ but not with carbenicillin. While hydrolysed by enzyme $A$, carbenicillin still appears to inhibit enzyme B, since strong synergy is shown by carbenicillin + cephalosporin $\mathrm{C}$ or carbenicillin + cephalothin. Bobrowski \& Borowski (I97I), who showed the inhibitory effect of carbenicillin on $\beta$-lactamases from Pseudomonas aeruginosa and Enterobacter, did not observe significant synergism between carbenicillin and cephaloridine, which was rapidly hydrolysed by these lactamases. They suggested that the absence of synergism could be explained by the high rate of penetration by cephaloridine through the surface layers of the organism and the existence of a permeability barrier to carbenicillin. In the present work, two $\beta$-lactam antibiotics were used (cephalosporin $C$ and cephalothin) which showed some crypticity and which were readily hydrolysed by the $\beta$-lactamase concerned. Moreover, the resistance to carbenicillin due to enzyme $A$ allowed the use of a relatively high concentration of this antibiotic in the synergy experiments. Assuming that the synergy between cloxacillin and other $\beta$-lactam antibiotics is an expression of the part played by enzyme $\mathbf{B}$ in the resistance to these antibiotics, an indication of the importance of $B$ in resistance can be obtained from the intensity of the synergy. The differences between the resistance levels of H66 (B only) and the other group 3 strains $(A+B)$ provides an indication of the role of the A-type $\beta$-lactamase.

A striking indication of the effect of the enzymes on resistance is provided by the activity of carbenicillin, which is only slightly hydrolysed by $\mathbf{A}$ and is a strong inhibitor of $\mathbf{B}$. On the other hand, the m.i.c. values of cephaloridine are low in spite of the high rate of hydrolysis of this substrate by both enzymes. However, with cephaloridine relatively high $K_{m}$ values could lower the effectiveness of the enzyme in vivo. The $K_{m}$ value of A (W222) for 
cephaloridine is $175 \mu \mathrm{M}(\simeq 70 \mu \mathrm{g} / \mathrm{ml})$ while it is only $39 \mu \mathrm{M}(\simeq \mathrm{I} 4 \mu \mathrm{g} / \mathrm{ml})$ for benzylpenicillin (Cornelis \& Abraham, I975). In addition to this, the 'crypticity factor' for cephaloridine is extremely low and, as shown by Hamilton-Miller (1963) and Richmond \& Sykes (1973), the higher the crypticity factor for a substance, the higher tends to be the protection by a given $\beta$-lactamase.

Resistance pattern of group $5 \mathrm{~b}$. The sensitivity to carbenicillin and the uniform synergy between cloxacillin and other $\beta$-lactam antibiotics observed in group $5 \mathrm{~b}$ can be explained by the lack of type A $\beta$-lactamase revealed by starch gel electrophoresis. The fact that the profile of the crude extract of strain M77I (group $5 \mathrm{~b}$ ) is similar to that of B (from strain W222), agrees with this conclusion. The resistance to ampicillin observed with the strains of group $5 \mathrm{~b}$ remains unaccounted for in view of the type $\mathrm{B} \beta$-lactamase profile. Moreover, the synergy with cloxacillin + ampicillin observed with these strains raises the question whether the B enzyme is actually involved in this resistance. The same kind of situation was, however, observed with Escherichia coli: some strains selected for ampicillin resistance were found to produce a $\beta$-lactamase with extremely low activity against ampicillin (Smith, 1963; Lindström, Boman \& Steele, 1970). Similarly, Roupas \& Pitton (1974), in a survey of ampicillin resistance in $E$. coli, found some ampicillin-resistant strains which synthesized a cloxacillin-sensitive $\beta$-lactamase with extremely low activity in vitro against ampicillin (profile $\mathrm{E}$ of these authors). A synergy cloxacillin + ampicillin provided evidence, also, for an effect of the lactamase in the ampicillin resistance.

Resistance patterns of groups I, 2 and 16 . With the strains belonging to group 2, electrophoresis of crude extracts showed the presence of a type $\mathrm{A}$ and a type $\mathbf{B} \beta$-lactamase. The type A enzyme was still predominant, in agreement with the specific activities against cephalosporin $\mathrm{C}$ and the m.i.c. pattern. Strains from groups $\mathrm{I}$ and $\mathrm{I} 6$ are highly resistant to carbenicillin and there is synergy between cloxacillin, or carbenicillin, and other $\beta$-lactam antibiotics with these strains. This suggests strongly that the strains have a two-enzyme system, but no clear confirmation of the presence of two $\beta$-lactamases was obtained by gel electrophoresis. It is possible that, within these groups, the enzymes corresponding to $\beta$-lactamases A and B have similar electrophoretic mobilities under the conditions used.

G.C. is Aspirant du Fonds National de la Recherche Scientifique, Brussels, Belgium. He thanks Professor E. P. Abraham and M. Berks-McPhail (University of Oxford) for helpful discussions and critical reading of the manuscript. He is also grateful to Professer G. Wauters (Université de Louvain) for his strains and helpful discussions, and to Professor A. Trouet and Dr de Barsy (ICP, Woluwe) for use of equipment.

Corrigendum. In G. Cornelis \& E. P. Abraham (1975), Journal of General Microbiology 87, pp. $273^{-284}$, on p. 276 , line 3 of Results: for 'about $7 \times 10^{-1}$ ' read 'about $7 \times 10^{-2}$ '.

\section{REFERENCES}

Aldova, E. \& Lim, D. (I974). Yersinia enterocolitica in small rodents. I. Pilot study in two wildlife areas. Zentralblatt für Bakteriologie, Parasitenkunde, Infektionskrankheiten und Hygiene (Abteilung I) 226, $49 \mathrm{I}-496$.

Bobrowski, M. \& Borowski, E. (197I). Interaction between carbenicillin and $\beta$-lactamases from Gramnegative bacteria. Journal of General Microbiology 68, 263-272.

Cornelis, G. \& Abraham, E. P. (1975). $\beta$-Lactamases from Yersinia enterccolitica. Journal of General Microbiology 87, 273-284.

Cornelis, G., Wauters, G. \& Vanderhaeghe, H. (1973). Presence de $\beta$-lactamase chez Yersinia enterocolitica. Annales de Microbiologie (Institut Pasteur) 124B, 139-152. 
ERICSSON, H. M. \& SHERRIS, D. C. (I97I). Antibiotic sensitivity testing. Report of an international collaborative study. Acta pathologica et microbiologica scandinavica B 217 (supplement).

Hamilton-Miller, J. M. T. (1963). Penicillinase from Klebsiella aerogenes. Biochemical Journal 87, 209-214.

HAMilton-MilleR, J. M. T. (I97I). The demonstration and significance of synergism between $\beta$-lactam antibiotics. Journal of Medical Microbiology 4, 227-237.

Hamilton-MilleR, J. M. T., SMith, J. T. \& KNOX, R. (1964). Potentiation of penicillin action by inhibition of penicillinase. Nature, London 201, 867-868.

JACK, G. W. \& RICHMOND, M. H. (1970). A comparative study of eight distinct $\beta$-lactamases synthesized by Gram-negative bacteria. Journal of General Microbiclogy 6r, 43-6I.

Lindström, E. B., Boman, H. G. \& Steele, B. B. (1970). Resistance of Escherichia coli to penicillins. VI. Purification and characterization of the chromosomally mediated penicillinase present in amp Acontaining strains. Journal of Bacteriology Ior, 218-23I.

Mishankin, B. N., RyzhKo, I. V. \& Grigorian, E. G. (I973). Study of penicillinase activity of Pasteurella pseudotuberculosis and Pasteurella X. Antibiotiki 18, 621-624.

NiLhen, B. (1967). Studies on Yersinia enterocolitica. Acta pathologica et microbiologica scandinavica 69, 83-91.

NiLHEN, B. (1969). Studies on Yersinia enterocolitica: with special references to bacterial diagnosis and occurrence in human acute enteric disease. Acta pathologica et microbiologica scandinavica 206 (supplement).

RIChmond, M. H. \& Sykes, R. B. (1973). The $\beta$-lactamases of Gram-negative bacteria and their possible physiological role. Advances in Microbial Physiology 9, 3I-88.

Roupas, A. \& PITTON, J. S. (1974). R factor-mediated and chromosomal resistance to ampicillin in Escherichia coli. Antimicrobial Agents and Chemotherapy 5, 186-191.

Sabath, L. D. \& Abraham, E. P. (1964). Synergistic action of penicillins and cephalosporins against Pseudomonas pyocyanea. Nature, London 204, 1066-1069.

SмIтH, J. T. (1963). Penicillinase and ampicillin resistance in a strain of Escherichia coli. Journal of General Microbiology 30, 299-306.

SMITHIES, O. (I955). Zone electrophoresis in starch gels: group variations in the serum proteins of normal human adults. Biochemical Journal 6r, 629-64I.

SUTHERLAND, R. \& BATCHELOR, F. R. (1964). Synergistic activity of penicillins against penicillinase-producing Gram-negative bacilli. Nature, London 201, 868-869.

Wauters, G. (1970). Contribution à l'étude de Yersinia enterocolitica. Thesis, University of Louvain. Edited by Vander.

Wauters, G., Le Minor, L. \& Chalon, A. M. (1971). Antigénes somatiques et flagellaires des Yersinia enterocolitica. Annales de l'Institut Pasteur 120, 631-642.

Wauters, G., Le Minor, L., Chalon, A. M. \& Lassen, J. (1972). Supplément au schema antigénique de Yersinia enterocolitica. Annales de l'Institut Pasteur 122, 95I-956.

WinbLaD, S. (1967). Studies on serological typing of Yersinia enterocolitica. Acta pathologica et microbiologica scandinavica 187 , SII5.

WINBLAD, S. (1968). Studies on O antigen factors of Yersinia enterocolitica. In International Symposium on Pseudotuberculosis. Symposia Series in Immunobiological Standardisation, vol. 9. Basle: Karger.

Zen-YoJi, H. \& Maruyama, T. (1972). The first successful isolations and identifications of Yersinia enterocolitica from human cases in Japan. Japanese Journal of Microbiology 16, 493-500.

Zen-You, H., Maruyama, T., Sakai, S., Kimura, S., Mizuno, T. \& Momose, T. (1973). An outbreak of enteritis due to Yersinia enterocolitica occurred at a junior high school. Japanese Journal of Microbiology 17, 220-222. 